\author{
DARIUSZ IWAN ${ }^{1}$, PIOTR DASZKIEWICZ ${ }^{2}$ \\ ${ }^{1}$ Muzeum i Instytut Zoologii PAN \\ Wilcza 64, 00-679 Warszawa \\ ${ }^{2}$ Instytut Historii Nauki PAN \\ Nowy Świat 72, 00-330 Warszawa \\ E-mail:darek@miiz.waw.pl \\ piotrdas@mnhn.fr
}

\title{
SZYMON TENENBAUM (1892-1941) - ŻYCIORYS SPISANY NA ENTOMOLOGICZNEJ ETYKIECIE
}

Szymon Tenenbaum urodził się 31 stycznia 1892 r. w Warszawie w rodzinie pochodzenia żydowskiego. Jego żona, Eleonora, w 1947 r. przekazała Państwowemu Muzeum Zoologicznemu (PMZ) zarówno księgozbiór, jak i kolekcję chrząszczy, które stanowiły

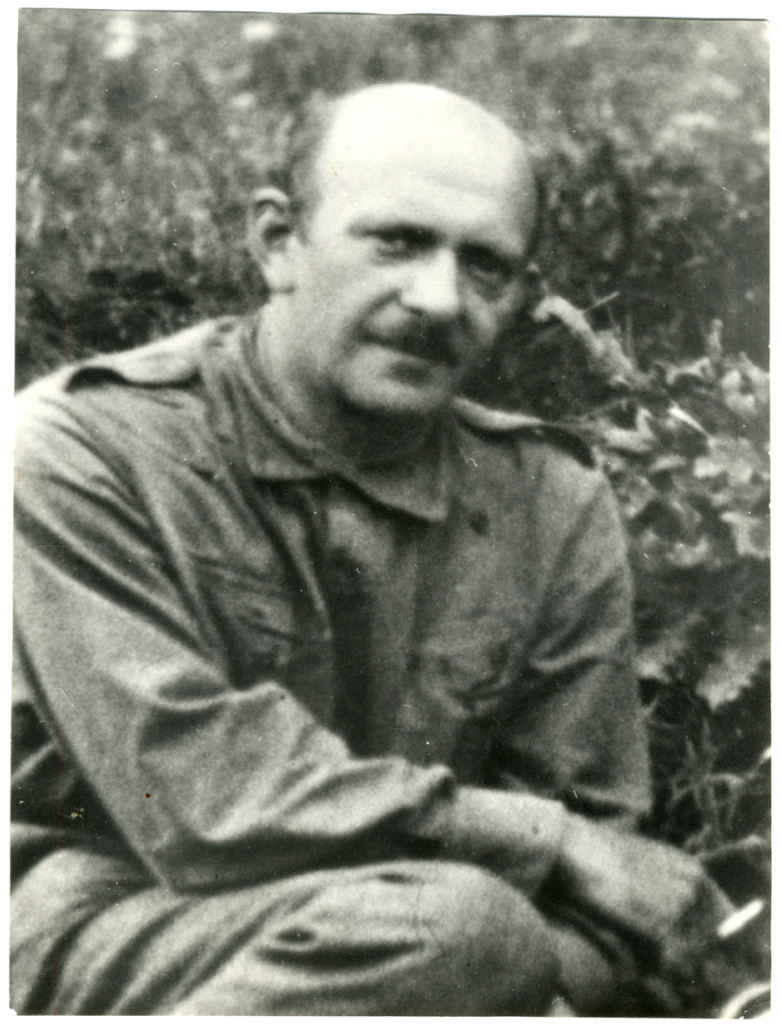

Szymon Tenenbaum (1892-1941) własność rodziny. Rodziny, która doświadczyła tragedii holokaustu - przeżyła tylko żona słynnego entomologa. Tenenbaum związany był z PMZ w okresie 20-lecia międzywojennego, nie tylko jako członek korespondent, ale również naukowiec, który ratował i porządkował zbiory entomologiczne po pożarze w 1935 r., a także autor kolekcji zoologicznej, o wyjątkowym znaczeniu, wybiegajacym poza wartość naukowa zwykłych kolekcji owadów. Tenenbaum zmarł w getcie warszawskim 29 listopada 1941 r., jednak jego zbiór chrzasszczy przetrwał II wojnę światowa chroniony w Ogrodzie Zoologicznym w Warszawie w „Willi pod zwariowana gwiazda". Dom ten odegrał istotna rolę przy wyprowadzeniu $z$ getta i uratowaniu wielu osób przez Jana i Antoninę Żabińskich. W czasie Powstania Warszawskiego kolekcja Tenenbauma przechowywana była w piwnicy budynku PMZ przy ul. Wilczej $64 \mathrm{w}$ Warszawie. Zbiór ponad 250000 etykiet muzealnych dołączonych do okazów chrzasszczy stanowi olbrzymi zasób danych umożliwiajacych odtworzenie miejsc i dat pobytu wielkiego entomologa, a także ustalenie jego współpracowników. W kolekcji Tenenbauma, jako nabytki, znajdują się również okazy pozyskiwane w czasach Gabinetu Zoologicznego przez najwybitniejszych polskich przyrodników takich jak: Antoni Waga, Władysław Taczanowski, Ksawery i Aleksander Braniccy, Benedykt Dybowski, Konstanty Jelski, Ludwik Hildt. Okazy te sa jednymi $z$ nielicznych jakie zachowały się $\mathrm{w}$ polskich kolekcjach. W 1944 r., po upadku Powstania Warszawskiego, Niemcy celo-

*Artykuł powstał dzięki wsparciu finansowemu z projektu POPC.02.03.01-00-0081/19 „Integracja i mobilizacja danych o różnorodności biotycznej Eukaryota w zasobach polskich instytucji naukowych” (IMBIO). 
wo podpalili budynek Muzeum i zniszczyli najcenniejsze polskie zbiory entomologiczne. Straty materialne i osobowe PMZ doskonale oddaja ogólny obraz zniszczeń nauki polskiej w czasie II wojny światowej, których skutki odczuwalne sa do dziśs.

\section{Szymon Tenenbaum (1892-1941)}

Szymon Tenenbaum was born on January 31, 1892 in Warsaw to a family of Jewish origin. His wife, Eleonora, in 1947 donated both the book collection and the collection of beetles owned by the family to the State Zoological Museum (PMZ). The family that experienced the tragedy of the Holocaust - only the wife of the famous entomologist survived. Tenenbaum was associated with the PMZ during the interwar period, not only as a correspondent member, but also a scientist who saved and organized the entomological collections after the fire in 1935, and the author of a zoological collection of exceptional importance, exceeding the scientific value of ordinary collections of insects. Tenenbaum died in the Warsaw ghetto on November 29, 1941, but his collection of beetles survived World War II, protected in the Zoological Garden in Warsaw in the "Villa under a crazy star". This col-

\section{WSTEP}

W 1964 r. ukazał się w Przeglądzie Zoologicznym obszerny życiorys Szymona Tenenbauma (PRÜFFER i WOLSKI 1964). Maszynopis tej pracy gotowy był już w czerwcu 1946 r. i nosił tytuł "Działalność naukowa s. p. Dr Szymona Tenenbauma". Zarówno ten dokument, jak i materiały przesłane przez żonę słynnego entomologa, Eleonore Tenenbaum-Krajewska (1892-1967), przechowywane sa w Archiwum Muzeum i Instytutu Zoologii PAN (MiIZ PAN) (sygn. PMZ 2294 i PMZ 2295 oraz zbiór J. Domaniewskiego). Wszelka korespondencja w tej sprawie kierowana była do dyrektora Państwowego Muzeum Zoologicznego Stanisława Feliksiaka, który zainicjował akcję szacowania strat wynikających z działań okupanta niemieckiego w czasie II wojny światowej (DASZKIEWICZ $i$ IWAN 2016). Straty materialne i osobowe Państwowego Muzeum Zoologicznego doskonale oddaja ogólny obraz zniszczeń nauki polskiej, których skutki odczuwalne sa do dziś.

Szymon Tenenbaum zwiazany był $z$ PMZ w okresie 20-lecia międzywojennego, nie tylko jako członek korespondent, ale również naukowiec, który ratował i porządkował zbiory entomologiczne po pożarze w 1935 r., a także autor kolekcji zoologicznej o wyjątkowym znaczeniu, wybiegajacym poza war- lection played an important role in escorting the ghetto and saving many people by Jan and Antonina Żabiński. During the Warsaw Uprising, Tenenbaum's collection was stored in the basement of the PMZ building at ul. Wilcza 64 in Warsaw. The collection of over 250,000 museum labels attached to beetle specimens is an enormous amount of data enabling the reconstruction of the places and dates of the great entomologist's stay and the determination of his associates. The Tenenbaum collection, as acquisitions, also includes specimens obtained during the time of the Zoological Cabinet by the most outstanding Polish naturalists such as: Antoni Libra, Władysław Taczanowski, Ksawery and Aleksander Branicki, Benedykt Dybowski, Konstanty Jelski, Ludwik Hildt. These specimens are among the few that have survived in Polish collections. In 1944, after the fall of the Warsaw Uprising, the Germans set fire to the Museum building and destroyed the most valuable Polish entomological collections. The material and personal losses of the $P M Z$ perfectly reflect the overall picture of the devastation of Polish science during World War II, the effects of which are still felt today.

tość naukową zwykłych kolekcji owadów. Jego żona w 1947 r. przekazała PMZ zarówno księgozbiór, jak i kolekcję chrząszczy, które stanowiły własność rodziny. Rodziny, która doświadczyła tragedii holokaustu - przeżyła tylko Eleonora. Zachowane dokumenty, zdjęcia i listy pokazuja niezwykle mocna więź duchowa, jaka łaczyła wszystkich jej członków. Córka Tenenbauma, Irena (Ryc. 1), razem $z$ ojcem jeździła na wycieczki entomologiczne, pomagała $\mathrm{w}$ preparowaniu owadów i opiekowała się nim w czasie cięż-

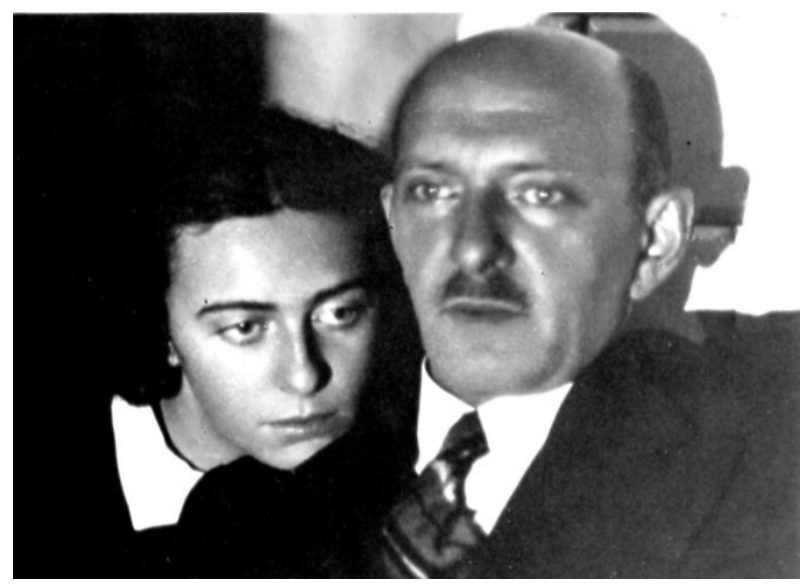

Ryc. 1. Szymon Tenenbaum (1892-1941) z córka Irena, getto warszawskie. Archiwum MiIZ PAN. 


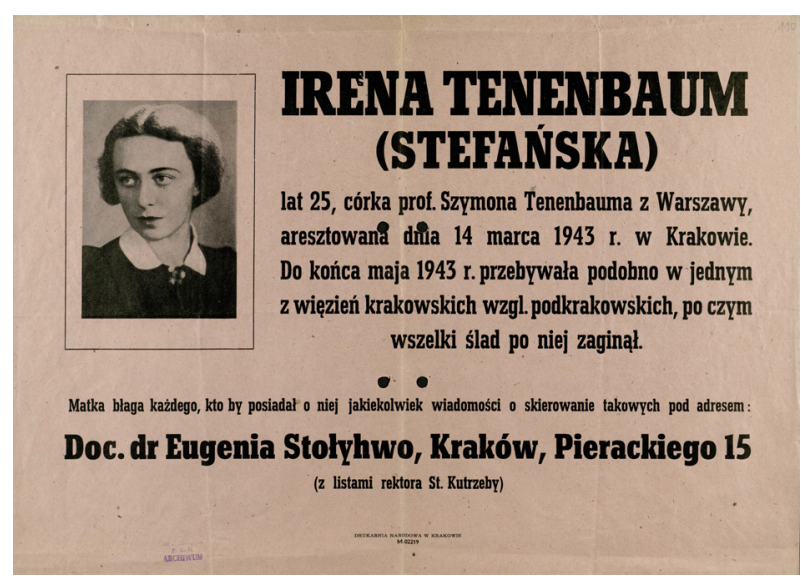

Ryc. 2. Ogłoszenie wydrukowane w czasie powojennych poszukiwań córki Szymona Tenenbauma. Archiwum MiIZ PAN.

kiej choroby w getcie. Po śmierci ojca uciekła $z$ getta i pojechała do Krakowa, gdzie została aresztowana i zaginęła, a jej powojenne poszukiwania nie przyniosły rezultatu (Ryc. 2). Losy Szymona Tenenbauma i jego bliskich, a także historia ratowania zbioru chrząszczy, stanowiły inspirację dla pisarzy i filmowców. Wydarzenia te były bezpośrednio zwiąane $z$ działalnościa okupacyjna Antoniny i Jana Żabińskich (patrz ZBONIKOWSKA 2020) z Warszawskiego ZOO, których Instytut Pamięci Męczenników i Bohaterów Holokaustu Yad Vashem w Jerozolimie uhonorował w 1965 r. tytułem Sprawiedliwy wśród Narodów Świata.

Pożoga wojenna pochłonęła nie tylko ludzkie życie, ale również spuściznę naukową (notatki, maszynopisy) i wszelkie dokumenty osobiste wielu polskich przyrodników (BRZEK 1997). Na szczęście, w przypadku Szymona Tenenbauma, odnajdowanych jest

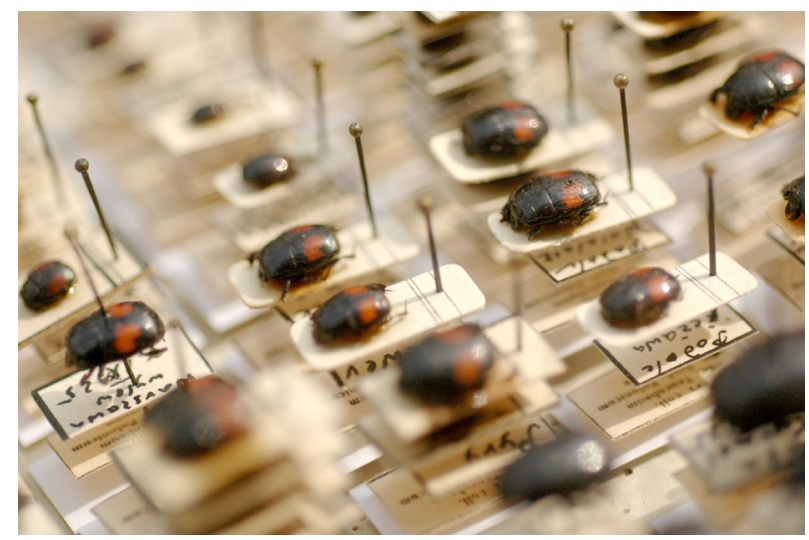

Ryc. 3. Fragment gabloty $z$ kolekcji chrzaszczy Szymona Tenenbauma przechowywanej w zbiorach zoologicznych Muzeum i Instytutu Zoologii PAN w Warszawie, fot. P. Szymroszczyk. coraz więcej dokumentów archiwalnych, m. in. listów, a prace związane $z$ analizą jego zbiorów zoologicznych prowadzone sa $\mathrm{z}$ coraz większym rozmachem. Naukowiec $\mathrm{w}$ ciagu całego życia przekazał do kolekcji muzealnych na całym świecie kilkaset tysięcy okazów zwierząt reprezentujących różne grupy taksonomiczne, głównie owady. Największy, autorski zbiór chrząszczy, przechowywany obecnie $\mathrm{w}$ Muzeum i Instytucie Zoologii PAN w Warszawie (Ryc. 3), jest przedmiotem digitalizacji w ramach projektu „Integracja i mobilizacja danych o różnorodności biotycznej Eukaryota w zasobach polskich instytucji naukowych" (IMBIO).

\section{ŚRODOWISKO RODZINNE}

Szymon Tenenbaum urodził się 31 stycznia 1892 r. w Warszawie w rodzinie pochodzenia żydowskiego. Jego ojciec, Bernard, przywoził $z$ licznych podróży zagranicznych wiele pamiątek, w tym okazy przyrodnicze. Matka, Franciszka, prowadziła dom wychowując dwójkę synów, Szymona i Stefana, który zaginą we Francji w czasie I wojny światowej.

Grób Szymona Tenenbauma znajduje się na cmentarzu żydowskim w Warszawie przy ul. Okopowej. Zarówno żona, w swoich listach do Janusza Domaniewskiego, jak i autorzy biografii (PRÜFFER i WOLSKI 1964, KOWALSKA 1987) podaja 29 listopada $1941 \mathrm{r}$. jako datę śmierci entomologa. Natomiast na tablicy nagrobkowej widnieje inskrypcja „Szymon Tenenbaum, doktor nauk przyrodniczych, żył 49 lat, zmarł 29 VI 1941 r, cieniom zaginionej naszej ukochanej córeczki Irenki". Tablica ta powstała już po wojnie, na co wskazuje zapis dotyczacy Ireny. Wydaje się, że kamieniarz wykonujący tablicę błędnie odczytał „XI” jako „VI”.

Istnieje jednak nadal rozbieżność co do dnia śmierci. Na stronie internetowej Centralnej Biblioteki Judaistycznej widnieje oryginalny nekrolog o treści: „B. P. Szymon Tenenbaum, przyrodnik, Korespondent b. Państwowego Muzeum Zoologicznego, b. członek Komisji Fizjograficznej Warsz. Tow. Naukowego i Komisji Fi[z]jograficznej Akad. Umiejętn. W Krakowie, b. dyrektor gimnazjum „Laor”, zmarł dnia 28-go listopada 1941 r. - przeżywszy 49 lat, pogrzeb odbędzie się z domu przedpogrzebowego przy ul. Okopowej dn. 1. XII o godz. 3-ej po poł. O czym zawiadamiają żona i córka".

$\mathrm{Na}$ stronach CBJ opublikowane zostały również informacje $z$ karty żałobnej prezentowanej w Gazecie Żydowskiej w 1941 r.: „jeden $z$ najtęższych umysłów naukowych zmarł - znakomity przyrodnik. Przewodniczacy R[ady] Ż[ydowskiej] w uznaniu zasług 
zmarłego udzielił $\mathrm{Mu}$ honorowego grobu, a pochowanie odbyło się na koszt Gminy".

\section{STUDIA NA UNIWERSYTECIE JAGIELLONSSKIM}

W archiwum Uniwersytetu Jagiellońskiego znajduja się dokumenty przedstawiajace studia Szymona Tenenbauma, które odbył w latach 1910-1918, w sumie 6 semestrów. Opracowane dokumenty znajduja się w Archiwum Uniwersytetu Jagiellońskiego, nosza sygnatury: WF II 362, 1910/11 IIp, WF II 369, 1912/13 Ip, WF II 374, 1913/14 Ip, WF II 376, 1913/14 IIp, WF II 382, 1917/18 Ip, WF II 383, 1917/18 IIp.

Na podstawie wpisów do ksiag studentów nadzwyczajnych Wydziału Filozoficznego prowadzonych przez Dziekanat i Kwesturę można odtworzyć przebieg studiów, a także zapoznać się $z$ danymi personalnymi studenta (Ryc. 4). $Z$ wpisów poczynionych w kolejnych latach dowiadujemy się $\mathrm{m}$. in. o miejscach zamieszkania Tenenbauma w Krakowie: ul. Garncarska 17, ul. Radziwiłłowska 15, plac Kossaka 8, ul. Florjańska 14, ul. Czapskich 1 , podane jest również „imię, zatrudnienie i miejsce zamieszkania ojca lub opiekuna: Bernard, na prywatnej posadzie, Warszawa, Śto Krzyska 39", a w roku szkolnym 1917/18 (półrocze zimowe i letnie) „Bernard, kupiec, Moskwa”. Następne rubryki to: „religia: Żyd”, w kolejnych latach „w. mojżeszowe”, „Mojżeszowa”; „narodowość: Polak”, „polska”; „poddaństwo: Rosyjskie", a w roku szkolnym 1917/18 (półrocze zimowe) „poddaństwo: Pol-

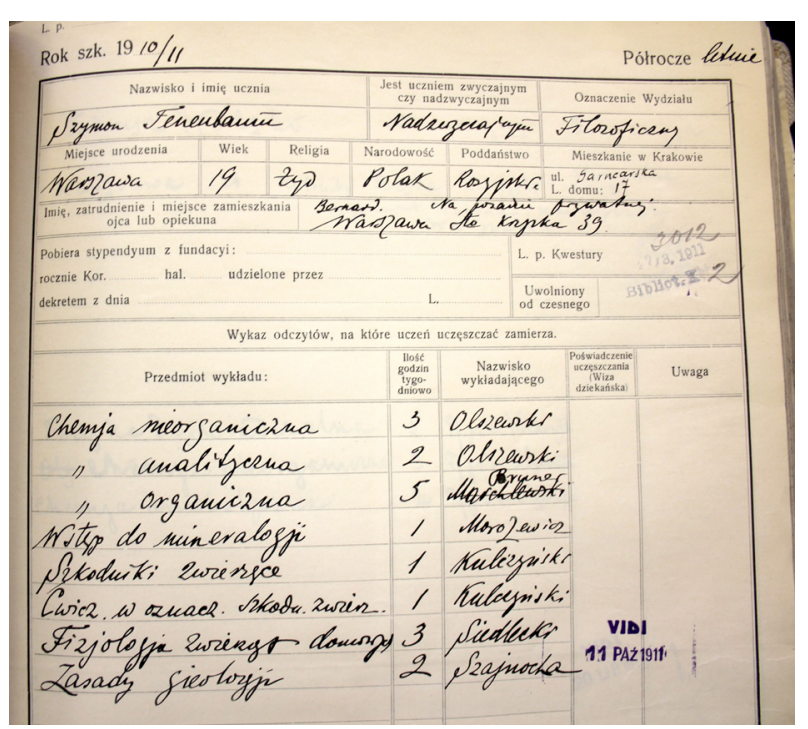

Ryc. 4. Wpis dotyczący Szymona Tenenbauma w księdze studentów nadzwyczajnych Wydziału Filozoficznego Uniwersytetu Jagiellońskiego prowadzonych przez Dziekanat w latach 1910/11. Archiwum UJ. skie", natomiast w semestrze letnim rubryki maja brzmienie: „Religia: Żyd”, „Język ojczysty: polski”, „Poddaństwo: Król. Pol.”. Uzupełnienie stanowi „miejsce urodzenia: Warszawa” i „wiek: 19 [w kolejnych latach 20, 21, 22, 25, 1892]". Dodatkowe dane wskazują na to, że student Sz. Tenenbaum nie „pobiera stypendium $z$ fundacyi” oraz nie jest „uwolniony $z$ czesnego".

Przedmioty, które student chciał studiować, były wpisywane jako „Wykaz odczytów, na które uczeń uczęszczać zamierza", jednak $\mathrm{w}$ niektórych przypadkach nie potwierdzono realnego udziału w wykładach, stad zapisy te były w księgach wykreślane (nie zostały niżej przytoczone).

Rok szkolny 1910/11, półrocze letnie: chemja nieorganiczna (3 godziny tygodniowo) i analityczna (2) wykładowca - Olszewski, chemja organiczna (5) - Bruner, wstęp do mineralogji (1) - Morozewicz, szkodniki zwierzęce (1) i ćwiczenia w oznaczaniu szkodników zwierzęcych (1) - Kulczyński, fizjologia zwierzat domowych (3) - Siedlecki, zasady gieologji (2) - Szajnocha.

Rok szkolny 1912/13, półrocze zimowe: anatomia porównawcza ustroju nerwowego (2) - prof. Hoyer, Echinodermata (3) - prof. Siedlecki, botanika ogólna (4) - prof. Raciborski, roślinność zwrotnikowa (1) - prof. Raciborski.

Rok szkolny 1913/14, półrocze zimowe: paleontologja ogólna (3) - prof. Grzybowski, Anatomia porównawcza zmysłów (2) - prof. Hoyer, mięczaki (publiczne, 1) - prof. Siedlecki, fizjologia roślin (4) - prof. Godlewski sen., rozród i dziedziczność (publiczne, 1) prof. Godlewski jun., pracownia dla samodzielnie prac. (codziennie) - prof. Hoyer

Rok szkolny 1913/14, półrocze letnie: botanika systematyczna (5) - prof. Raciborski, ogólna histologia (4) - prof. Hoyer, biologja ogólna cz I. (3) - prof. Godlewski, pracownia chemiczna (9) - prof. Olszewski.

Rok szkolny 1917/18, półrocze zimowe: logika i zasady badań (4) - Rubczyński, paleontologia systematyczna (3) - Grzybowski, rozbiór wybranych utworów krytyki romantyczne (2) - Chrzanowski, teorya transcendencyi (1) - Kossuth.

Rok szkolny 1917/18, półrocze letnie: Zoologia systematyczna i ogólna (5) - prof. Siedlecki, dzieje filozofii od śmierci Sokratesa (4) - prof. Rubczyński, niezniszczalność ducha jako problem etyczny i metafizyczny (1) - prof. Rubczyński.

\section{SPRAWA DOKTORATU NA UNIWERSYTECIE JAGIELLONSKIM}

22 kwietnia 1919 r. Szymon Tenenbaum złożył prośbę o pozwolenie przystapienia do 
egzaminów doktorskich na ręce Dziekana Wydziału Filozoficznego W. Kleckiego, kierowane „Do Świetnego Wydziału Filozoficznego Uniwersytetu Jagiellońskiego w Krakowie". $\mathrm{Na}$ dokumencie znajdujemy dopisek: JEPanu Profesorowi Drowi Hoyerowi przesyłam $Z$ prośba o wydanie opinii na najbliższym posiedzeniu Wydziału. $\mathrm{Na}$ podaniu widnieje również podpis i adres zamieszkania Tenenbauma: Warszawa, ul. Wielka $\mathrm{Nr}$ 54. Egzaminy doktorskie miały obejmować anatomię porównawcza wraz $z$ zoologia jako przedmiot główny oraz paleontologie jako przedmiot dodatkowy. Kandydat dołaczył do podania krótki życiorys datowany na 17 kwietnia 1919 r.: W roku 1909 wystapitem z powodu choroby z 7ej klasy VIIio klasowego gimnazjum realnego $p$. Kreczmara $w$ Warszawie. $W$ roku 1910 zostałem przyjęty jako słuchacz nadzwyczajny na Wydział Filozoficzny Uniwersytetu Jagiellońskiego, gdzie przebyłem 6 semestrów. Przez ten czas pracowałem $w$ pracowni anatomji porównawczej prof. Hoyera. W ciagu kilkuletniej przerwy $w$ studjach przebywałem $w$ Warszawie $i$ pracowałem $w$ pracowni Zoologicznej Towarzystwa Naukowego, a ostatnio w Muzeum Zoologicznym Uniwersytetu Warszawskiego. Jako wynik mych studjow ogłosiłem rozprawy, $z$ których 6 załaczam. W razie uzyskania przychylnej decyzji Świetnego wydziału, jako prace doktorska przedstawiam prace p. t. „Przyczynek do historyi rozwoju osłon jajowych $u$ Haematopsinus suis L.". Obecnie moje prace zawodowe $i$ ciężkie położenie materjalne uniemożliwiaja mi zdawanie egzaminów maturalnych. Pragnac jednak uzyskać stopień doktora Uniwersytetu Jagiellońskiego, proszę Świetny Wydział o uwzglednienie okolicznosci $w$ jakich sie znajduje $i$ dopuszczenie mnie do egzaminów pomimo braku matury". Na marginesie dokumentu znajduję się ręczny przypisek: "8 prac naukowych oraz indeks $w$ imieniu p. Sz. Tenenbauma otrzymałem, Dr Tadeusz Wolski".

Do prośby załączone zostało obszerne Curriculum vitae: Urodziłem sie $w$ Warszawie 31.I.1892. W roku 1900 wstapiłem do wstepnej klasy szkoły Zgromadzenie Kupców; $w$ roku 1907 przeszedłem do 6ej klasy VIio klasowej Szkoły Realnej p. Kreczmara, $w$ r. 1909 wystapiłem z powodu choroby z VIIej kl. tejże szkoły. W r. 1910 wstapiłem jako stuchacz nadzwyczajny na Wydział filozoficzny Uniwersytetu Jagiellońskiego i prowadziŁem studja $i$ prace naukowe $w$ pracowni prof. Hoyera $w$ zakresie zoologji. Wojna zastała mnie $w$ Warszawie, $w$ nauce uniwersyteckiej nastapiła więc kilkuletnia przerwa. W Warszawie pracowałem $w$ pracowni Zoologicznej Towarzystwa Naukowego. W r. 1917/18 ukończyłem studja me $w$ Krakowie. Obecnie jestem nauczycielem gimnazjalnym $w$ Warszawie. Prace swoje naukowe rozpoczałem jeszcze w gimnazjum. W latach 1907-1909, tz. zn. jako uczeń $k l$. V-VII próbowałem pracować nad rozmaitemi zagadnieniami $z$ dziedziny zoologji $w$ pracowni $w$ pracowni Towarzystwa Ogrodniczego $i w$ r. 1909 zostałem wydelegowany przez Polskie Towarzystwo Krajoznawcze do Ordynacyi Zamojskiej $w$ gub. Lubelskiej $w$ celu studjów nad owadami. Częściowe wyniki tych badań ogłosiłem $w$ r. 1913. W latach 1910-12 podczas pobytu $w$ Krakowie $w$ pracowni prof. Hoyera rozpoczałem szereg prac z których jednak większość nie została do końca doprowadzona, podczas wojny bowiem przepadło mi dużo materjałów. Zajmowały mnie wówczas kwestje regeneracji, oraz stosunek jadra do protoplazmy $w$ naczyniach wydzielniczych owadów. W roku 1913 odbyłem podróż naukowa na wyspy Balearskie. Z ogromnej ilości materjałów zebranych na wyspach część tylko, mianowicie chrzaszcze, płazy i gady zostały już opracowane, pluskwiaki przygotowuje do druku, mięczaki (kilka tysięcy okazów) z braku literatury obecnie nie moga być opracowane. Podczas paroletniej przerwy $w$ studjach przebywałem $w$ Warszawie pracujac na anatomja owadów $w$ pracowni Zoologicznej Towarzystwa Naukowego, ostatnio zaś opracowuje materjały peruwiańskie w Muzeum Zoologicznym Uniwersytetu Warszawskiego.

Od roku 1916 jestem nauczycielem gimnazjalnym $w$ Warszawie. Wakacje $i$ święta przepedzam na wsi gromadzac materjały faunistyczne. W okolicach Warszawy zbieram chrząszcze, któremi się głównie zajmuję od $r$. 1906. Rezultatem mych poszukiwań było zebranie, i opracowanie około 200 tysiecy okazów. Uważajac, że materjał został już należycie wyzyskany (około 3200 gatunków) prace zakończyłem $i$ oddałem do druku do XXVI t. Pamiętnika Fizyograficznego; obejmuje ona mniej wiecej 350 stron druku; ze wzgledu na ilość gatunków podanych $z$ jednego terenu bedzie to największa praca fizyograficzna $w$ ogóle.

Tenenbaum przedstawił wykaz 12 publikacji, które ukazały się drukiem oraz plany opracowań naukowych sformułowane w następujacych punktach: 1. Prostoskrzydle wysp Balearskich, 2. Pluskwiaki wysp Balearskich, 3. Pluskwiaki $z$ Białowieży $i$ Polesia, 4. Pluskwiaki okolic Warszawy, 5. Chrzaszcze Pienin, 6. Monografja biedronek (Coccinellidae) ziem polskich, 7. Nowe gatunki chrzaszczy peruwiańskich (ze zbiorów Muzeum Zoologicznego Uniwersytetu Warszawskiego i zbiorów Muzeum Przemysłu $i$ Rolnictwa), 8. Nowe gatunki chrzaszczy syberyjskich (z tychże Muzeów). 
2 maja 1919 r. odbyło się w Krakowie posiedzenie Rady Wydziału Filozoficznego Uniwersytetu Jagiellońskiego. W protokole znajdujemy nazwiska uczestniczacych w posiedzeniu naukowców: Rubczyński, Klecki, Sikorski, Godlewski, Sternbach, Hoyer, Talko-Hryncewicz, Natanson, Szajnocha, Banachiewicz, Siedlecki, Garbowski, Zaremba, Semkowicz, Birkenmajer, Sinko, Heinrich, Zakrzewski, Dziewoński, Grzybowski, Szafer, Sobieski, Jachimecki, Windakiewicz, Rogoziński, Rozwadowski, Łoś, Chrzanowski, Mycielski, a przy punkcie 13 „Podanie p. Tennenbauma [błą $\mathrm{w}$ pisowni] o dopuszczenie do rygorozów. Ref. Prof. Hoyer." ręczny dopisek „Wniosek jednomyślnie przyjęto”. Dodatkowo w archiwum znajduje się dokument, który prawdopodobnie sporządził prof. Hoyer: Dziekanat Wydz. fil. Uniwer. Jag. Poświadcza niniejszem, że p. T został uchwała Rady Wydziatu z r 9/V 1919 na podstawie 4 lat wystuchanych na wydz. filoz. $w$ charakterze słuch. nadzwyczajnego oraz przedłożonych prac naukowych dopuszczony do egzaminów ścisłych.

Nie wiemy dlaczego Tenenbaum nie obronił doktoratu na Uniwersytecie Jagiellońskim. Czy już wtedy atmosfera wśród społeczności uniwersyteckiej nie sprzyjała studentom narodowości żydowskiej? Dopiero 12 maja 1932 r. współpraca $z$ profesorem Janem Prüfferem umożliwiła Tenenbaumowi uzyskanie dyplomu doktora filozofii na Uniwersytecie Stefana Batorego w Wilnie. W tym czasie był już autorem lub współautorem 25 oryginalnych publikacji naukowych oraz ksiażek, takich jak „Podręcznik do zbierania $i$ kolekcjonowania zwierzat" (TENENBAUM 1923), czy też „Krótki zarys owadoznawstwa" (PRÜFFER i TENENBAUM 1923) dotyczacy chrząszczy szkodliwych $\mathrm{w}$ gospodarce leśnej. Jego studia faunistyczne chrząszczy Zamojszczyzny objęły aż 2299 gatun- ków. Sprawa doktoratu, zarówno krakowskiego, jak i wileńskiego wyjaśnia, dlaczego to właśnie Tadeusz Wolski (1890-1959) i Jan Prüffer (1890-1959) byli autorami biogramu Szymona Tenenbauma napisanego w 1946 r. Obaj uczeni nie dożyli jego druku w 1964 r.; Tadeusz Wolski zmarł 21 maja 1959 r. w Łodzi, a Jan Prüffer kilka miesięcy później, 30 grudnia 1959 r. w Toruniu.

Tenenbaum $z$ cała pewnościa identyfikował się ze swoim narodem, był Żydem. Jednak czuł się również Polakiem, czego wyraz dał nazywając nowy dla nauki gatunek Isomira polonica Tenenbaum, 1922 (TANENBAUM 1922), a jako obywatel prezentował postawę, o której PRÜFFER i WOLSKI (1964) pisali: Tenenbauma należy zaliczyć do bezpośrednich ofiar wojny, ofiar, które nigdy nie chcialy poddać sie wrogowi $i$ do ostatniego tchnienia uważały sie za żolnierzy Polski. Taka postawe Tenenbaum miat zawsze, czy to $w$ okresie strajku szkolnego, czy to tworzacego sie Zwiazku Strzeleckiego, czy to $w$ okresie grasujacej „Falangi”, czy wreszcie $w$ ciężkich chwilach oblężenia Warszawy $i$ wrażej okupacji.

O stosunku młodego entomologa do rosyjskiego zaborcy niech świadczy przytoczony poniżej cytat $z$ listu do Janusza Domaniewskiego napisanego $\mathrm{w}$ Moskwie w dniu 2 listopada 1914 r.: Gdym pierwszy raz byt $w$ Kremlu stakem palac papierosa $w$ niemej kontemplacji przed "car puszka”. Wypaliwszy go, zrobilem to samo co Ty, ogarek wrzuciŁem do lufy. Ciekawym czy prócz nas jeszcze kto miat taki pomyst.

\section{ŻYCIORYS SPISANY NA \\ ENTOMOLOGICZNEJ ETYKIECIE}

Analiza danych zawartych na muzealnych etykietach umożliwia odtworzenie wielu faktów z życia entomologa: poznanie jego
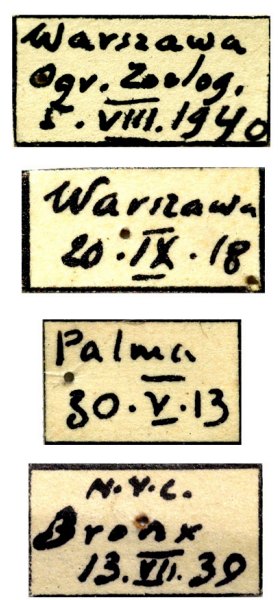
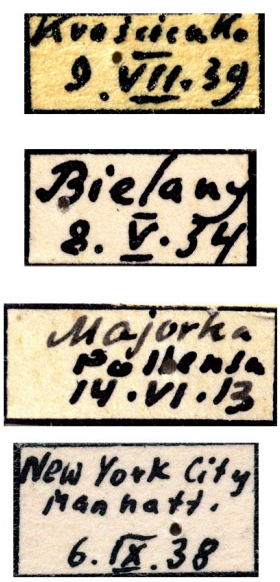
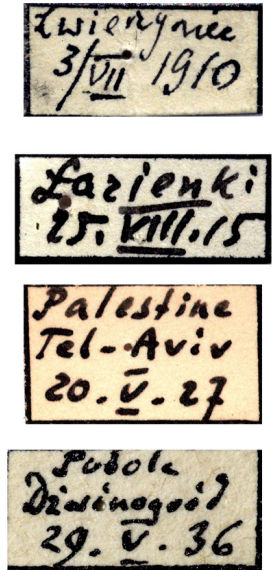

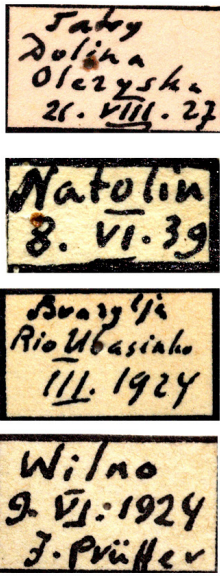

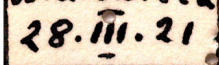
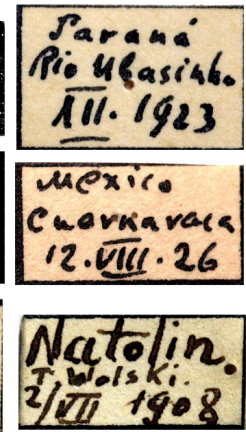

Ryc. 5. Etykiety entomologiczne w kolekcji chrząszczy Szymona Tenenbauma, fot. P. Szymroszczyk. 
znajomych i współpracowników, nie tylko ze środowiska entomologicznego, czy też miejsc i czasu pobytu badacza (Ryc. 5). Obecnie szacuje się, że kolekcja liczy około 250000 okazów. Materiały w niej zgromadzone były zebrane i opracowywane przez ponad 100 lat przy współudziale ponad 260 entomologów $z$ całego świata.

Niestety, nie udało się potwierdzić informacji o istnieniu kolekcji entomologicznej utworzonej przez Tenenbauma po 16 października 1940 r., czyli po zamknięciu getta warszawskiego. Natomiast analiza materiałów zbieranych w 1940 r. warszawskim Ogrodzie Zoologicznym przyniosła ciekawe spostrzeżenia. Ogród nie stanowił wcześniej dla entomologa ważnego terenu badań, stąd w okresie przedwojennym w zbiorach znajdujemy tylko 4 daty zbioru chrząszczy: 13.04.35, 19.03.38, 16.09.38 i 02.04.39. Natomiast niezwykle intensywny okres wizyt i połowów w ZOO przypada na okres od maja do końca września 1940 r. W sumie przynajmniej 19 razy Tenenbaum był na warszawskiej Pradze w Ogrodzie Zoologicznym: 12.05.40,17.05.40, 29.05.40, 07.06.40,

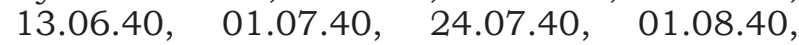
05.08.40, $11.08 .40, \quad 25.08 .40, \quad 30.08 .40$, 08.09.40, 10.09.40, 16.09.40, 18.09.40, 19.09.40, 21.09.40, 23.09.40. W tym czasie odłowił blisko 3000 okazów chrząszczy należących do 21 rodzin, $z$ czego ponad połowa przypada na rodzinę kusakowatych (Staphylinidae). Już wtedy zapewne przygotowywał się do opuszczenia swojego mieszkania, które mieściło się w kamienicy przy ul. Chmielnej 9 i przesiedlenia do dzielnicy żydowskiej na ul. Orlą. Czy właśnie wtedy przenosił na Prage, na drugi brzeg Wisły, swoje zbiory entomologiczne do „Willi pod zwariowana gwiazda", a księgozbiór do mecenasa Popoffa (KOWALSKA 1987) [prawdopodobnie chodzi o Eugeniusza Popoffa (1890-1963)]? Oba zbiory zostały w 1947 r. podarowane Państwowemu Muzeum Zoologicznemu w Warszawie przez żonę Tenenbauma.

Czy to wtedy Jana Żabińskiego i Szymona Tenenbauma połączyła przyjaźń i wspólne zainteresowania? Mimo że byli znanymi zoologami, to niewiele osób wiedziało, że prawdziwą pasją badawcza obu naukowców była fizjologia rozrodu owadów, badania eksperymentalne i laboratoryjne. Jan Żabiński nie tylko był znanym hodowca i dyrektorem Ogrodu Zoologicznego, $z$ cała pewnościa należał również do grona entomologów. Do oceny dorobku naukowego w przewodzie habilitacyjnym przeprowadzonym i zakończonym nadaniem stopnia doktora habilitowanego w 1946 r. na Uniwersytecie Marii Curie-Skłodowskiej w Lublinie, oprócz jednej publikacji o żubrach, przedstawił 4 inne artykuły doty- czace budowy narządów rozrodczych, aktów kopulacyjnych, biologii, rozwoju postembrionalnego i odżywiania u karaczanów (Blattodea). Szymon Tenenbaum, którego opublikowany dorobek naukowy dotyczy badań fizjograficznych i systematycznych, jako temat rozprawy doktorskiej przedstawił wyniki badań nad rozwojem osłon jajowych wszy świńskiej. Czy wybrałby taki kierunek badawczy $i$ zrobił kariere naukowca uniwersyteckiego, gdyby mógł pracować w instytucji naukowej i kontynuować prace, które prowadził jako student w krakowskiej pracowni prof. Henryka Ferdynanda Hoyera (18641947), późniejszego rektora Uniwersytetu Jagiellońskiego, członka i wiceprezesa Polskiej Akademii Umiejętności?

W opracowaniu "Getto warszawskie. Przewodnik po nieistniejacym mieście" (ENGELKING i LEOCIAK 2013) znajdziemy bardzo dużo dat i faktów, które moga pomóc $w$ wyjaśnieniu przyczyny tak częstych wizyt w ZOO. W kwietniu 1940 r. Niemcy wznowili prace nad planami założenia getta w Warszawie, a wokół przyszłej dzielnicy żydowskiej zaczęto wznosić mury; w czerwcu 1940 Zarzą Miejski zostaje powiadomiony o przewidywanych granicach getta, ul. Chmielna nie będzie do niego włączona; w lipcu 1940 r. wstrzymano rozwój koncepcji getta, wróciły rozważania nad przeniesieniem milionów europejskich Żydów na Madagaskar, jednak 18 lipca zostaja wprowadzone drastyczne ograniczenia w poruszaniu się Żydów po Warszawie, m. in. zakaz wstępu do parków publicznych; sierpień 1940 - zarządzenie Leista dotyczace przyszłej dzielnicy żydowskiej powoduje duże poruszenie i zamieszanie; wrzesień 1940 - akcja przesiedlenia Żydów rozszerza się, „oczyszczane” sa różne ulice, głównie te w okolicy Chmielnej (Żurawia, Wspólna, Hoża, Wilcza, Marszałkowska, Królewska); 2 października 1940 r. Fischer podpisuje zarzadzenie o utworzeniu getta w Warszawie, a 16 listopada getto zostaje zamknięte, ulica Chmielna zostaje po aryjskiej stronie. 138000 Żydów i 113000 Polaków musiało zmienić miejsce zamieszkania - na obszarze 307 ha powierzchni zabudowanej znalazło się blisko 400000 Żydów, wśród nich rodzina Szymona Tenenbauma.

$\mathrm{Na}$ podstawie informacji zawartych na entomologicznych etykietach możemy dzień po dniu odtworzyć ostatnią wyprawę Tenenbauma w Pieniny, która trwała od połowy lipca aż do 28 sierpnia 1939 r. Badania prowadził głównie w okolicy Czorsztyna i Krościenka, często zbierał owady w „Dolinie potoku Pienińskiego", a także w okolicy takich miejsc jak „Zamek Św. Kingi”, Trzy Korony, Czertezik, Ociemne, Szczawnica, Golica, Stolarzówka, Łupisko, Sokolica, Homle, 
etc. etc. W sumie w zbiorach znajduje się nie mniej niż 10000 okazów chrząszczy zebranych w Pieninach, blisko 3000 z Puszczy Białowieskiej, około 30000 z Podola oraz 40000 z Warszawy i okolic. Obecne analizy prowadzone $\mathrm{w}$ oparciu o materiały zawarte w kolekcji zapewne doprowadza do odtworzenia wykazu gatunków, które były zamieszczone w maszynopisach uznanych za zaginione podczas II wojny światowej. Najobszerniejszym opracowaniem była monografia chrzasszczy Warszawy i okolic liczaca blisko 1000 stron, która miała być wydana na koszt miasta za sprawa Prezydenta Warszawy Stefana Starzyńskiego (1893-1939), czy też "Zoogeograficzne rozmieszczenie chrzaszczy" - maszynopis zawierajacy wyniki badań prowadzonych na Mazowszu, w Tatrach, Pieninach, Wileńszczyźnie i Podolu, którego współautor profesor Roman Kuntze (19021944), podobnie jak Tenenbaum nauczyciel tajnych kompletów, zginą podczas Powstania Warszawskiego.

Kolekcja Tenenbauma zawiera szereg ciekawych, czasami tajemniczych zbiorów okazów. Czy okaz chrząszcza zebrany 12 września 1939 r. w okolicy Otwocka (Śródborów, rów przeciwlotniczy) jest dowodem, że Tenenbaum brał udział w obronie Warszawy?

Kilka tysięcy okazów znajdujacych się w kolekcji świadczy o tym, że w czasie podróży na Bliski Wschód na przełomie 1925/26 odwiedził takie miejsca jak Tel Aviv, Hajfa, Jabata, Jerycho, Migdal, Rosz Pina, Safed, Tyberiada, Ein Harod (kibuc), a nowy rok spędził w Jerozolimie. Nie wiemy kto organizował ten wyjazd i kolejny w 1927 r. Czy były one jakoś zwiazane $z$ Czwarta Alija, która trwała w latach 1924-1931? W okresie tym w Palestynie osiedliło się ponad 60000 Żydów polskich, a 1 kwietnia 1925 r. w Jerozolimie powstał Uniwersytet Hebrajski.

W jaki sposób w zbiorach Tenenbauma znalazło się blisko 1000 okazów chrząszczy zbieranych pomiędzy 22 maja 1938 r. a 1 grudnia 1939 r. w okolicy Nowego Jorku - N.Y.C.: Bronx, Coney Island, Copake Falls, Copake West, Croton Falls, Denville, Manhattan, Palisades, Rockaway, Staten Isl. Atlantic, Van Cortland Park, Wantagh? Czy przysłał je swojemu nauczycielowi i mistrzowi Borys Malkin (1917-2009), uczeń Gimnazjum Humanistycznego Męskiego Towarzystwa "LAOR”, w którym Tenenbaum był nauczycielem przyrody i dyrektorem? Ten wybitny antropolog i zoolog, badacz kultur Indian Ameryki Południowej w 1938 r. wyemigrował do Stanów Zjednoczonych. Na początku swojego pobytu mieszkał w Nowym Jorku, gdzie nawiazał pierwsze kontakty $z$ entomologami należącymi do towarzystw naukowych zwiazanych $z$ Brooklyn Museum i
American Museum of Natural History. 17 lutego 1947 r. żona Tenenbauma w liście do Janusza Domaniewskiego pisze: ... wracając do Szymeczka! nie pamiętam, czy Ci mówiŁam, że po Jego śmierci przyszedt list z Ameryki od jego ucznia Borysa Malkina, z pierwsza jego praca owadziarska (chrzaszcze) poświęcona Szymkowi. Jakby sie Szym cieszył!! W 2019 r. środowisko amerykańskich entomologów ponownie zetknęło się $z$ sylwetka Borysa Malkina, w kontekście losów jego nauczyciela i mistrza. Na corocznym spotkaniu Entomological Collections Network, które odbyło się w St. Louis na zaproszenie organizatorów został wygłoszony referat pt. "A life story written on entomological labels" (Marcin Kamiński, Dariusz Iwan), w którym przedstawiona została historia Szymona Tenenbauma i jego kolekcji chrzaszczy.

Zbiory Tenenbauma sa jednymi $z$ najmniej znanych, a przy tym bardzo cennych kolekcji powstałych na przełomie XIX/XX w. Wiedza na ten temat jest niewielka, gdyż wspomina się o niej jedynie w kontekście samej sylwetki autora (PRÜFFER i WOLSKI 1964, ŻABIŃSKA 1968, KOWALSKA 1987, BUNALSKI i współaut. 2001). Większość dostępnych publikacji dotyczy przede wszystkim jego krajowych badań terenowych prowadzonych na Roztoczu (TENENBAUM 1913, 1918) oraz materiałów pozyskanych w czasie wypraw zagranicznych na Balearach (TENENBAUM 1914, 1915a, b), w Brazylii (TENENBAUM 1927) oraz Meksyku (TenenBAUM i WolsKi 1928).

Osobny rozdział w dorobku naukowym Szymona Tenenbauma stanowi opracowanie gadów i płazów Balearów (TENENBAUM 1915c), niezwykle wysoko ocenione przez naukowców hiszpańskich (DAszKIEwICZ i BAUER 2010).

Projekt digitalizacji kolekcji chrzaszczy zdeponowanych w zbiorach MIiZ PAN w ramach realizacji IMBIO umożliwi udostępnienie informacji szerszemu gronu odbiorców poprzez portal Mapa Bioróżnorodności (BioMap) i Global Biodiversity Information Facility (GBIF). Analiza danych $z$ etykiet pozwoli na wykonywanie opracowań naukowych, głównie faunistycznych, ale również na ustalenia dotyczące badań i życia Szymona Tenenbauma. W kolejnym etapie digitalizacji wykonywane będa zdjęcia okazów, a w przypadku cennych eksponatów, majacych znaczenie historyczne lub/i taksonomiczne np. typy opisowe, przygotowywane będa modele $3 \mathrm{D}$.

\section{PODZIEKOWANIA}

Autorzy składaja podziękowania Panom Marcinowi Kamińskiemu za pomoc w redagowaniu maszynopisu i Przemysławowi 
Szymroszczykowi za wykonanie zdjęć (Pracownia Muzeum MiIZ PAN) oraz Pani Marii Główce (Archiwum MilZ PAN w Warszawie) za życzliwość i wieloletnia pomoc.

\section{LITERATURA}

BRZEKK G., 1997. Straty wśród zoologów polskich $w$ nastepstwie II wojny światowej. Analecta. Studia i Materiały z Dziejów Nauki 6, 173197.

Bunalski M., LIPA J. J., Nowacki J., 2001. Almanach entomologów polskich. Wiadomości Entomologiczne XX suplement. Polskie Towarzystwo Entomologiczne, Poznań.

DASZKIEWICZ P., BAUER A. M., 2010. Szymon Tenenbaum, a forgotten contributor to the herpetology of the Balearic Islands. Bol. Asoc. Herpetol. Esp. 21, 132-138.

DASZKIEWICZ P., IWAN D., 2016. Straty wojenne Państwowego Muzeum Zoologicznego - raport Stanisława Feliksiaka (1906-1992). Pamięć i Sprawiedliwość 27, 431-439.

ENGELKING B., LEOCIAK J. 2013. Getto warszaw skie. Przewodnik po nieistniejacym mieście. Stowarzyszenie Centrum Badań nad Zagłada Żydów, Warszawa.

KOWALSKA K. 1987. Szymon Tenenbaum. [W:] Słownik biologów polskich. FELIKSIAK S. (red.). Warszawa, Państwowe Wydawawnictwo Naukowe, 544.

PRÜFfer J., Tenenbaum Sz. 1923. Szkodniki leśne. [W:] Krótki zarys owadoznawstwa. PRÜFFER J. (red.). Trzaska, Evert, Michalski, Warszawa, 1-106.

PRÜFFER J., WOLSKI T. 1964. Działalność naukowa doktora Szymona Tenenbauma. Przegląd Zoologiczny 8, 5-9.

TENENBAUM Sz. 1913. Chrzaszcze (Coleoptera) zebrane $w$ Ordynacyi Zamojskiej $w$ gub. Lubelskiej. Pamiętnik Fizyograficzny 21, 3-72.
Tenenbaum Sz. 1914. Nowe gatunki chrzaszczy z wysp Balearskich. Rozprawy Wydziału Matematyczno-Przyrodniczego Akademii Umiejętności. Dział B. Nauki Biologiczne 54, 195-201.

TENENBAUM Sz. 1915a. Fauna koleopterologiczna Wysp Balearskich. Pracownia Biologiczna T. M. P., Gebethner i Wolff, Warszawa, 1-150.

Tenenbaum Sz. 1915b. Nowy chrzaszcz balearski. Pracownia Biologiczna T.M.P., Gebethner i Wolff, Warszawa, 1-3.

Tenenbaum Sz. 1915c. Gady i płazy Wysp Balearskich. Pracownia Biologiczna T.M.P., Gebethner i Wolff, Warszawa, 1-16.

Tenenbaum Sz. 1918. Dodatek do spisu chrzaszczy z Ordynacyi Zamojskiej. Pamiętnik Fizyograficzny 25, 1-36.

TENENBAUM Sz. 1922. Isomira polonica n. sp. Rozprawy Wydziału Matematyczno-Przyrodniczego Polskiej Akademji Umiejętności. Dział B. Nauki Biologiczne 61, 27-28.

Tenenbaum Sz. 1923. 1. Mallophaga-Wszoły. 2. Anoplura-Wszy. 3. Aphaniptera-Pchty. 4. Coleoptera-Chrzaszcze. [W:] Podrecznik do zbierania $i$ konserwowania zwierzat należacych do fauny polskiej. POLIŃSKI W. (red.). Jan Cotty, Warszawa, 5, 1-60.

TENENBAum Sz. 1927. Wykaz chrzaszczy z podrodziny Cassidini (Coleoptera) zebranych $w \mathrm{~Pa}$ ranie. Prace Zool. Pol. Państw. Muzeum Przyrod. (Annales Mus. Zool. Pol.) 6, 34-38.

TENENBAUM Sz., Wolski T. 1928. Sprawozdanie z wycieczki zoologicznej do Meksyku. Prace Zool. Pol. Państw. Muzeum Przyrod. (Annales Mus. Zool. Pol.) 7, 22-31.

ZBONIKOWSKA O., 2020. Jan Żabiński - zoolog, wizjoner, polak, demokrata.... Kosmos 69, 243252.

ŻABIŃSKA A., 1968. Ludzie i zwierzęta. Czytelnik, Warszawa. 